\title{
EDITORIAL
}

\section{Social Distancing for Patients and Doctors? A New Post- COVID World}

\author{
Sandro Rizoli \\ Panamerican Journal of Trauma, Critical Care \& Emergency Surgery (2021): 10.5005/jp-journals-10030-1325
}

The coronavirus disease-2019 (COVID-19) pandemic has made words such as "social distancing", "self-isolation", and "quarantine" part of our daily vocabulary. Not a day goes by that we are not reminded of their importance in containing the spread of the virus. While social distancing and self-isolation have helped contain the pandemic, they have also distanced patients from doctors.

As an ordinary patient, physical distancing transformed my regular doctor visits to online. Some visits are by videoconference, while others by phone. While I am thankful to colleagues that continued to care for me, I can state that "it is not the same". As a surgeon, I must follow the same distancing rules. On many occasions, I felt "distant care" was inadequate, and many patients were invited to in-person encounters during the pandemic.

While distancing patients from doctors, COVID-19 caused an explosion of telemedicine and virtual hospitals, which were already growing before the pandemic. Telemedicine transformed patient care and advanced medical education to levels never thought before. A few months ago, Dr Marttos (USA) led online the Critical Decisions in Trauma course in Qatar, which would be unattainable a few years ago.

Despite the telemedicine advances, I miss some of the patientdoctor interaction. Much of the patient's experience starts with the nurse or doctor greeting-in the outpatient clinic or trauma resuscitation bay. Trust in the team, starts at the first minute of the encounter. There is also the restriction to physical examination if not in person, plus many human interactions that cannot happen at distance. One consequence of the new order (arguably) is the evergrowing reliance on laboratory tests and imaging. I will show my age by confessing that in medical school, semiology (history taking + physical examination) was among the longest courses (three semesters). I still remember a professor proudly affirming that not every patient needs lab tests or imaging - if you take the history and examine them.

In the XXI century, caring for the injured is almost impossible without CT scans, ultrasounds, INR, and thromboelastography. Major decisions in trauma and emergency situations are directly affected by image and laboratory results. However, I believe decisions are "affected" more than "imposed" by them. In theory, history and physical examination still reign above all. Maybe it will change in the post-COVID era, fortunately along with advances in telemedicine.

The present issue of the PAJTCCES continues the discussion on the effects of COVID. In a letter to the editor, Drs Moscote-Salazar (Colombia), Agrawal (India), and Rahman (Bangladesh) argue the consequences to the practice of neurocritical care. Two other manuscripts focus on major thoracoabdominal trauma. The study by Drs Fonseca Neto, Moutinho and Costa (Brazil) focus on early traumatic hepatothorax (liver herniation through the ruptured diaphragm). The other study by Drs Barillaro, Nazaretto et al. from
Department of Surgery, Trauma Section, Hamad Medical Corporation, Doha, Qatar

Corresponding Author: Sandro Rizoli, Department of Surgery, Trauma Section, Hamad Medical Corporation, Doha, Qatar, Phone: +974 6662 0521, e-mail: srizoli@hamad.qa

How to cite this article: Rizoli S. Social Distancing for Patients and Doctors? A New Post-COVID World. Panam J Trauma Crit Care Emerg Surg 2021;10(2):59-60.

Source of support: Nil

Conflict of interest: None

Argentine, explore which cavity to operate first in penetrating thoracoabdominal trauma, and the consequences of choosing the wrong one.

This issue has many other excellent manuscripts including airway management in massive hemoptysis, the effect of testing positive for methamphetamine on the outcome of injured patients in California, and the talk-and-die syndrome. Two papers I recommend to the members of the Panamerican Trauma Society. The first by Dr Himmler on the experience of a USA-trained surgeon over a year living in Ecuador (una extranjera en el extranjero). This paper in "global surgery" covers the topic of learning overseas and the "intangible human element" of surgery. The second is the paper by Dr Nancy Valencia-Roja, entitled "fostering knowledge transfer to strengthen the surgical workforce in LMIC". Dr Valencia-Roja analyses the 10-year experience of the International Observership Program (IOP) of the Virginia Commonwealth University (VCU) and Panamerican Trauma Society. The IOP created the opportunity for Latin American physicians to participate in the activities of the VCU in the United States. A reverse experience compared to that of $\mathrm{Dr}$ Himmler in Ecuador ("una extranjera en el extranjero").

Finally, I want to invite you to submit a manuscript for the upcoming special issue of the PAJTCCES. The official announcement will be published separately. The issue focus on TBI and spinal cord injury in different regions of the world. We look forward to a spectacular issue, but its success will depend on the participation of all of you. The invited editors of the special issue are Prof Rubiano (Colombia), Prof Alves (Portugal), and Dr Luis Moscote (Colombia). We look forward to the manuscript from your hospital.

My sincere gratitude to the members of the Editorial Board that have expertly-reviewed submissions without hesitation and on time. Thank you to Drs Salamea and Otollino, and Ms. Gladys Shanklin for disseminating the Journal.

Sandro Rizoli, MD PhD FRCSC FACS Editor-in-Chief 


\section{¿Distanciamiento social para pacientes y médicos? s - un nuevo mundo post-COVID}

La pandemia de COVID-19 ha hecho que palabras como "distanciamiento social", "autoaislamiento", "cuarentena" formen parte de nuestro vocabulario diario. No pasa un día sin que se nos recuerde su importancia para detener la propagación del virus. Si bien el distanciamiento social y el autoaislamiento han ayudado a contener la pandemia, también han distanciado a los pacientes de los médicos.

Como paciente, el distanciamiento físico transformó mis visitas regulares al médico en línea. Algunas visitas son por videoconferencia, mientras que otras por teléfono. Si bien estoy agradecido con los colegas que siguieron cuidándome, puedo afirmar que "no es lo mismo". Como cirujano, debo seguir las mismas reglas de distanciamiento. En muchas ocasiones sentí que la "atención a distancia" no era suficiente y muchos pacientes fueron invitados a encuentros en persona durante la pandemia.

Por otro lado, COVID-19 provocó una explosión en la telemedicina y los hospitales virtuales, que ya estaban creciendo antes de la pandemia. La telemedicina transformó la atención al paciente y la educación médica avanzada a niveles nunca imaginados. Hace unos meses, el Dr Marttos (EE. UU.) dirigió en línea el curso Decisiones Críticas en Trauma en Qatar, que sería inalcanzable hace unos años.

A pesar de los avances de la telemedicina, extraño la interacción médico-paciente. Gran parte de la experiencia del paciente comienza con el saludo del médico o la enfermera-en la clínica ambulatoria o en la sala de reanimación de traumatismos. Confianza en el equipo, empieza en el primer minuto del encuentro. También hay un examen físico que no es posible si no es en persona, y muchas interacciones humanas que pueden reducirse significativamente si no es en persona. Podría decirse que una consecuencia del nuevo orden es la dependencia cada vez mayor de las pruebas de laboratorio y las imágenes. Demostraré mi edad confesando que, en la facultad de medicina, la semiología (anamnesis y examen físico) estuvo entre los cursos más largos (3 semestres). Todavía recuerdo a un profesor afirmando con orgullo que no todos los pacientes necesitan pruebas de laboratorio o imágenes-si se toma el historial y se los examinan.

En pleno siglo XXI, el cuidado de los pacientes lesionados es casi imposible sin la tomografía computarizada, la ecografía, el INR y la tromboelastografía. Las decisiones importantes en situaciones de trauma y emergencia se ven directamente afectadas por las imágenes y los resultados de laboratorio. Sin embargo, creo que decisiones son más "afectadas" que "impuestas" por las pruebas. En teoría, la historia y la exploración física siguen dominando por encima de todo. Tal vez no por mucho tiempo, y ellas cambiarán en la era post-COVID, afortunadamente a lo largo de avances en telemedicina.

Este número de PAJTCCES continúa la discusión sobre los efectos de COVID. En una carta al editor, los Drs Moscote-Salazar (Colombia), Agrawal (India) y Rahman (Bangladesh) discuten sobre las consecuencias para la práctica del cuidado neurocrítico. Otros dos manuscritos se centran en los traumatismos toracoabdominales importantes. El estudio de los Drs Fonseca Neto, Moutinho y Costa (Brasil) se centran en el hepatotórax traumático temprano (hernia hepática por rotura del diafragma). El otro estudio de los Drs Barillaro, Nazaretto et al. de Argentina, exploran qué cavidad operar primero en el trauma penetrante toracoabdominal y las consecuencias de elegir la incorrecta.

Este número tiene muchos otros manuscritos excelentes, incluido el manejo de las vías respiratorias en la hemoptisis masiva, el efecto de la prueba positiva de metanfetamina en el resultado de los pacientes lesionados en California y el síndrome de hablary morir. Dos artículos que recomiendo encarecidamente leer. El primero del Dr Himmler sobre la experiencia de un cirujano capacitado en EE. UU. durante un año en Ecuador (una extranjera en el extranjero). Este artículo en "cirugía global" cubre el tema del aprendizaje en el extranjero y el "elemento humano intangible" de la cirugía. El segundo es el trabajo de la Dr Nancy Valencia-Roja, titulado "fomento de la transferencia de conocimiento para fortalecer la plantilla quirúrgica". El Dr Valencia-Roja analiza la experiencia de 10 años del Programa de Observación Internacional (IOP) de la Virginia Commonwealth University (VCU) y la Sociedad Panamericana de Trauma. El IOP brindó la oportunidad a los médicos de América Latina de participar en la VCU en los Estados Unidos. Una experiencia inversa a la del Dr Himmler en Ecuador ("una extranjera en el extranjero").

Finalmente, quiero invitarlos a enviar un manuscrito para el próximo número especial de PAJTCCES. El anuncio oficial se publicará por separado. El tema se centró en TBI y lesiones de la médula espinal en diferentes regiones del mundo. Esperamos un número espectacular, pero su éxito dependerá de la participación de todos ustedes. Los editores invitados del número especial son el Prof Rubiano (Colombia), el Prof Alves (Portugal) y Dr Luis Moscote (Colombia). Esperamos el manuscrito de su hospital.

Mi más sincero agradecimiento a los miembros del Comité Editorial que han revisado de manera experta las presentaciones sin dudarlo y a tiempo. Gracias a los Dres Salamea y Otolino, y Ms. Gladys Shanklin por la difusión de la Revista.

Sandro Rizoli, MD PhD FRCSC FACS Editor-en-Jefe 